\title{
Human factors errors and identification of causes of successful/unsuccessful completion of business projects
}

\author{
Radka Vaníčková ${ }^{*}$ \\ ${ }^{1}$ Institute of Technology and Business in České Budějovice, Faculty of Corporate Strategy, 37010 \\ České Budějovice, Czech Republic
}

\begin{abstract}
Managers often deal with uncertainty of a different nature in their decision processes. The objective of the contribution is to confirm or refute the facts published in professional literature including the opinions resulting from the erudition of the author of the paper claiming that human factor errors and identifying causes of successful / unsuccessful completion of business projects is a significant explicit factor. With regard to this finding, the paper will deal with the quintessence of the human factor positive/negative impact on the business projects success, as well as recognizing and prevention of negative impacts on the implementation of success/failure a business project. The theoretical part defines the influence of the human factor and correlation of a business project success/failure with the SMART method. The analytical part of the paper interprets the theoretical findings into practical models of project teams by means of comparison and erudition of the author of the paper. The final part proposes measures, suggestions and recommendations concerning the optimal setting of the human factor key values so that the personality positive/negative impact on the business project success is evaluated and from the socioeconomic perspective in terms of invested financial resources and the return of investment, from a substantive and time point of view. For the purposes of the contribution, the term "influence" can be divided into exogenous and endogenous, while "success" can be defined as a determinant of positive/negative fulfilment of expected vision and business strategy entities. In terms of project management, "project" is a set of individual and unique activities to implement a planned change or innovation in a given period of time using specific sources.
\end{abstract}

Key words: human factors errors, interest groups, project team, team roles, behavioural competence

\section{Introduction}

Project is a set of concrete activities aiming to achieve the objective pursued. It is determined by time, financial resources, and human and material resources. Most projects have a unique objective. Business projects are generated by project teams. Project objective is defined with regard to the originality and uniqueness of partial tasks, necessary flexibility, creativity,

*Corresponding author: vanickova@mail.vstecb.cz 
expertise, practical experience and professional skills, ambitions and self-realization, knowledgeable project team is build up with the aim to achieve the objective with higher value added and synergic effect of economic and social benefit. The basic attributes of the influence of individual personalities and interest groups affecting a business project success are defined [1].

\section{Data and methods}

\subsection{Human factor as characteristic}

The bearer of project activities, productivity and prosperity are people, that is, core employees and co-workers. The activity in a business and in a micro-enterprise business shows analogy of the human factor - project management [2], [3]. Project manager has necessary professional qualifications and specific knowledge in the field / discipline in the form of so-called hard skills, i.e. technical, methodical, language, knowledge, etc. [4]. In the case of manual workers' positions, this refers to e.g. service and maintenance of numerically controlled machines, setting standards, regulations and internal rules of protection of safety and health at work, etc. The examples of soft skills are e.g. the development of verbal and on-verbal communication skills, individual and team work, project team leadership [5], [6], conceptual and entrepreneurial thinking supporting recognition, understanding, critical thinking, constructive criticism and the willingness to accept criticism, willingness to risk taking, resistance to stress, conflict resolution and business negotiation in a way of team partner cooperation, the ability to adapt to a situation and to accept innovations [7], learning new things, assertiveness, self-reflection, recognizing moral and ethical values, tolerance, networking, etc. [8]. Techniques of mental work and hygiene are hard to measure, they are less tangible, but equally important. The ability to acquire and develop professional knowledge and practical skills is influenced mainly by the temperament including the environment in family. An example for a leadership position is assessment of the soft skills influence in relation to employees / co-workers engagement, motivation and satisfaction, or leadership and facilitation of work meetings [9].

Table 1. Basic specification of project manager competencies

\begin{tabular}{|l|l|}
\hline Communication skills & Listening, negotiation, presentation \\
\hline Organization skills & Planning, forecasting, controlling, setting KPI \\
\hline Team work & Motivation, empathy, creativity, emotional stability \\
\hline Leadership & $\begin{array}{l}\text { Vision, delegating tasks, setting a good example, positive } \\
\text { attitude }\end{array}$ \\
\hline Art of overcoming obstacles & Flexibility, ambition, perseverance \\
\hline Expertise & $\begin{array}{l}\text { Technical, technological, methodical, hard and soft skills, } \\
\text { practical experience }\end{array}$ \\
\hline
\end{tabular}

Source: Own processing.

\subsection{Influence of interest groups}

Interest groups are individuals or organizations actively involved in a project or whose interests are positively or negatively influenced by the project implementation or the result of a sub-project. Successful preparation, implementation, and completion of a project depends on the approach / behaviour / expected result of an individual as a bearer of a personality, but also as personalities of so-called interest groups. Significant determinants of success / failure are necessary for the interpretation at an early stage of a business project management, in a feasibility study with the support of the SWOT analysis with the aim to 
eliminate threats / limitations / milestones / risks [10] and to enhance the functionality of selecting suitable alternatives to strategic and business opportunities and development potential of the successful implementation of a business project - see Table 2 Important influential subjects.

Table 2. Important influential subjects

\begin{tabular}{|l|l|}
\hline Project organization & Defines assignment, influences employees in project \\
\hline Strategic management & $\begin{array}{l}\text { Executive and strategic management approve project parameters and } \\
\text { sources. }\end{array}$ \\
\hline Business owners & $\begin{array}{l}\text { Propose and formulate a strategy. In the case of inconsistent owner } \\
\text { structure, there is increased risk of negative influence }\end{array}$ \\
\hline Project team & $\begin{array}{l}\text { Choosing project team members, assignment of roles to individual } \\
\text { team members together with an authorised person in the position of a } \\
\text { project manager is a strong motivator and stabilizer of fulfilment / } \\
\text { successful completion of a business project. }\end{array}$ \\
\hline Customer - buyer & $\begin{array}{l}\text { Customer/buyer has a unique influence on the usefulness and } \\
\text { economic return of investment in a business project. }\end{array}$ \\
\hline Investor & $\begin{array}{l}\text { Banking institutions, shareholders, third subjects requiring prediction } \\
\text { of appreciated investment with setting business conditions and } \\
\text { acceptable risks of a business project. }\end{array}$ \\
\hline State institutions & $\begin{array}{l}\text { Government, legislative and control institutions influence compliance } \\
\text { with legal, tax and legislative conditions that each business entity takes } \\
\text { into account and calculates their amount. }\end{array}$ \\
\hline Other public and media & $\begin{array}{l}\text { Media, social, cultural, interest, and environmental centres can have } \\
\text { different preferences and personal interests. It is therefore essential to } \\
\text { find common solutions or acceptable compromise in order to enhance } \\
\text { open communication, conceptual and creative thinking, logical } \\
\text { thinking, and meaningful decision-making in favour of a clearly } \\
\text { defined business project objective. }\end{array}$ \\
\hline
\end{tabular}

Source: Own processing.

\subsection{Project team influence}

Each person is different, has different dispositions, approaches, abilities, and skills. However, even people with the same skills and competencies can act differently in a community [11]. Human factor has a significant impact on success/failure business project [12], since the basic management requirement is to choose a team, assign key competences, sub-competences and roles in the project with regard to professional and specific experience [13], period of implementation of successfully/unsuccessfully completed projects, personal traits and characteristics of individual project team members including the conformity. 
Table 3. Team roles according to M. R. Belbin

\begin{tabular}{|l|l|}
\hline Chairman, project manager & $\begin{array}{l}\text { dominant, stable, with a great share of soft skills; project leader, } \\
\text { leader at a social level, coordinator; his contribution to } \\
\text { discussions is properly formulated questions and answers }\end{array}$ \\
\hline Proposer, director & $\begin{array}{l}\text { active, impulsive, often dominant member of a project team; } \\
\text { manages team work, requires discipline and productivity }\end{array}$ \\
\hline Innovator & $\begin{array}{l}\text { intelligent individualist, opinion maker; foresighted, inspiring } \\
\text { for team members, brings new ideas }\end{array}$ \\
\hline Whistle-blower, controller & $\begin{array}{l}\text { rational and emotionally stable person; analyst with conservative } \\
\text { opinions }\end{array}$ \\
\hline Organizer, implementer & $\begin{array}{l}\text { conscientious, disciplined person; translates team decisions into } \\
\text { concrete tasks assigned to team members; works systematically }\end{array}$ \\
\hline Discoverer & $\begin{array}{l}\text { gathers ideas, contributes with his own invention; establishes } \\
\text { business contacts, gains external support, improvises }\end{array}$ \\
\hline Supporter & $\begin{array}{l}\text { team worker, team builder; enhances team work } \\
\text { team member, whose main characteristics are diligence, } \\
\text { precision, sense of order, time management with a high share of } \\
\text { control and legal awareness }\end{array}$ \\
\hline Finisher & $\begin{array}{l}\text { professional in a given field, with a specific specialization; } \\
\text { depending on the nature of a project, he has technical, economic, } \\
\text { and legal knowledge; often works as an expert from practice }\end{array}$ \\
\hline Specialist
\end{tabular}

Source: Own processing.

\subsection{Influence of project manager behavioural competence}

Project manager shall be chosen based on the interest in people and the awareness of interpersonal relationships. The term "behavioural competence" (hereinafter referred to as $\mathrm{BC}$ ) in relation to the human factor influence on the business project success/failure is a paradigm of the project manager's competencies and skills reflected in leading working groups and motivating them to work performance [14]. IPMA standards define sets of competencies including project management topics in the theoretical and conceptual, technical, empirical, and behavioural areas. The basic fragments are further divided into competency elements, while the behavioural competencies in the area of soft skills listed below consider fifteen basic elements.

Table 4. Behavioural competencies elements

\begin{tabular}{|l|l|l|}
\hline 1. & Leadership & $\begin{array}{l}\text { Leadership consists in motivating and leading the team to fulfilling the potential and } \\
\text { achieving project objectives. }\end{array}$ \\
\hline 2. & $\begin{array}{l}\text { Involvement } \\
\text { and motivation }\end{array}$ & $\begin{array}{l}\text { personal contribution of a project manager; due to his involvement, people align } \\
\text { themselves with the implementation of the project and assigned roles }\end{array}$ \\
\hline 3. & Self-control & $\begin{array}{l}\text { systematic and positive approach to dealing with everyday routine and stress } \\
\text { situations in a project team }\end{array}$ \\
\hline 4. & Assertiveness & $\begin{array}{l}\text { ability to present and defend own opinion, adopt an objective view; the art of } \\
\text { persuasion and factual argumentation; protection against conditional manipulation; } \\
\text { ability to say NO }\end{array}$ \\
\hline 5. & Relaxation & $\begin{array}{l}\text { ability to alleviate stress and tension; personal and team prevention against the burn- } \\
\text { out syndrome }\end{array}$ \\
\hline 6. & Openness & $\begin{array}{l}\text { Openness is defined as the ability to motivate other team members so that they can } \\
\text { see the value of their own opinion, loyalty in relation to self-expression and self- } \\
\text { realisation. }\end{array}$ \\
\hline 7. & \multicolumn{2}{c}{$\begin{array}{l}\text { Creativity is the ability of logical and conceptual thinking, the ability to think } \\
\text { originally, react flexibly with the use of imagination, tasks and plans visualisation, } \\
\text { association, constructional and creative fantasy in terms of increasing performance, } \\
\text { sensitivity, and intuition. }\end{array}$} \\
\hline 8. & $\begin{array}{l}\text { Result } \\
\text { orientation }\end{array}$ & $\begin{array}{l}\text { managerial skill - ability to focus on key objectives, set personal and team priorities } \\
\text { using the ABC methods and time management }\end{array}$ \\
\hline
\end{tabular}




\begin{tabular}{|c|l|l|}
\hline 9. & Performance & $\begin{array}{l}\text { managerial skill; the ability to effectively use time, resources, and human capital; } \\
\text { performance is a set of characteristics and disposition, preparedness to deliver } \\
\text { expected performance / outputs }\end{array}$ \\
\hline 10. & Discussion & $\begin{array}{l}\text { a form of work meeting, an efficient form of collective problem solution during } \\
\text { organizational, conceptual, and informative meetings }\end{array}$ \\
\hline 11. & Negotiation & $\begin{array}{l}\text { Negation between team members within a project and supplier-customer relations } \\
\text { is desirable for the purpose of successful business relations of the win-win type. } \\
\text { Managerial skills shall include mainly the negotiation strategy }\end{array}$ \\
\hline 12. & Conflicts and \\
crisis & $\begin{array}{l}\text { Conflict can be defined as a centre of conflicting interests or incompatible } \\
\text { personalities. The task of a project manager is to operatively tackle a crisis or } \\
\text { misunderstanding by means of motivating team using leadership to achieve } \\
\text { excellence. }\end{array}$ \\
\hline 13. & $\begin{array}{l}\text { Understang a reliable person means to build close and friendly working relationships with } \\
\text { the environment based on reliability, fair behaviour, straightforwardness, } \\
\text { decisiveness, and self-confidence. }\end{array}$ \\
\hline 15. & values & $\begin{array}{l}\text { A manager sees the value of people, organizations, and societal values, see the } \\
\text { quality of the people and the participants' points of view. }\end{array}$ \\
\hline
\end{tabular}

Source: Own processing.

In the theoretical part of the contribution on the topic of "Human factors errors and identification of causes of successful/unsuccessful completion of business projects", the author defined significant correlations of abilities and skills with which the human factor influences the implementation of the project. The more these paradigms are applied in user practice, the more the personality of a project manager/ leader is important in the interaction with the defined objectives and expected outputs [15]. Conversely, the more the competency model of a project manager / leader differs from the characteristic nature of behavioural competencies and leadership, the greater the risk of adverse influence on the success/failure and conduct of a business project is [16].

\section{Results}

Business projects management requirements for speed and efficiency of work, and conducting the project activities, minimization of overhead and wage costs often increase with the growing project life cycle and often move beyond higher demands of human admissibility and resistance mainly in the area of hard skills, specific and professional specializations, practical skills, and managerial competencies, mainly the technical and methodological, conceptual, empirical and behavioural ones, with a lack of limits to the development of human factor competencies. Only the ability of a concrete personality is limited. The erudition of the author $\dagger$ is the fact that there are no limits of the personality development possibilities. Each person sets their own alternatives acceptable without limitations at different stages of life and development influenced by their own ambitions reflected in the self-evaluation of the personality potential.

Another explicit finding of the author is the analysis of the degree of the human factor impact on business project success and comparison of the needs of hard versus soft skills. Both practical experience of the author and publicly accessible studies and documentation in various business sectors indicate higher share of soft skills in behavioural competencies compared to hard skills, e. g. technical, professional, specific, etc.

Briefly, it can be said that the higher influence of behavioural competencies is able to compensate a potentially lower technical and professional competence; or that the personality behavioural competencies enable rapid acquisition of technical knowledge applicable in the

${ }^{\dagger}$ The author has been active in business development and project management for a long time. 
business project. Based on the findings specified above it can be stated that a competent project manager / leader is able to conduct a business project successfully in various sectors, even in completely different business sectors.

\subsection{Positive influence of personality on business project success}

In order to demonstrate the positive influence of human factor on business project success/failure, we will define a completed Czech project. In order to protect personal data of the corporation selected and in compliance with the European General Data Protection Regulation (GDPR) for protecting personal data of a concrete manager, only general, not publicly available parameters of the selected project sector and management of the selected company.

Table 5. Basic definition of business project

\begin{tabular}{|l|l|}
\hline Sector & Civil engineering and constructing \\
\hline Name of project & Integrated parking system \\
\hline Final consumer & Municipality \\
\hline Position of project manager & Team leader \\
\hline Location & East Bohemia \\
\hline Project submitter & $\begin{array}{l}\text { Large constructing and design company operating in the } \\
\text { given field in the entire Czech Republic }\end{array}$ \\
\hline Number of project team members & 4 (Project leader, specialists and implementer) \\
\hline Method of implementation & $\begin{array}{l}\text { Acceptance of the contract by the consumer, } \\
\text { implementation of business project }\end{array}$ \\
\hline Sources & CZK 5,000,000 \\
\hline Time & 36 months \\
\hline
\end{tabular}

Source: Own processing.

The starting position of the selected business project - individual phases: Start-up. (Know-how, business meetings with municipalities and political clubs and associations, business lobbying, contracting documents, expert case and economic studies of return of resources, finding a business project investor). This part of a project, from vision to signing the implementation phase of the project embedded in the contract, handing over the successfully completed project to the investor, took 36 months. The management of the project was at its early stage intuitively led by common sense, since no similar business project had been implemented in the Czech Republic by then. It was necessary to create a compact development and professional project team that was able to cooperate flexibly with the maximum workload, integrity, ambitions, patience, but also possesses demonstrable negotiation skills.

The start-up phase was carried out by a four-member team:

Project manager: leader, visionary, innovator, author of the business project concept. This assertive person had predominant behavioural competitions, leadership, negotiation and presentation skills, creativity, and high share of the ability to involve and motivate the project team members. The expert part of the project and legal know-how was delegated to the other team member with a partial support of outsourcing service of a design office, which had been evaluated as the optimal alternative of cooperation in terms of resources and quality of the project.

Project specialist 1: Expert in the field of civil and labour law with overlapping corporate and contract law dealing with the issue of public procurement in an explicit team role dealt with the creating the legal framework of know-how, streamlining the corporate visions with the emphasis on functionality, efficiency, and viability of the business project in the medium 
and long terms, and with the elimination of risks to prevent later legal failure. This person had a majority share of legal know-how and decision-making competence in technical areas of assessment in terms of risk management, implementation of outputs / impacts on the individual solutions to partial problems, the issue of contractual relations and the quality of business project documentation. In terms of conceptual competence, the specialist 1 excelled in the area of result orientation related to the issue of corporate and contract law. In terms of behavioural competencies, the emphasis was put on reliability, responsibility, ethics of moral behaviour and mutual communication, involvement, and devotion.

Project specialist 2: Expert in the field of economics with a focus on planning, controlling, budgeting, tax records and reporting to project submitter. Specialist 2 had highly specialized technical skills in the field of business economics and economy. Specialist 2 was an owner of a consultancy and advisory centre, an external lecturer at the University of Economics in Prague, the Czech Republic, and lecturer at several educational centres of renowned companies in the Czech Republic. This specialist had a minority share of soft skills in the area of behavioural competencies, e. g. the art of open and shared communication, listening, negotiating, communicating with people, resolving conflicts, and dealing with stress and crisis situations. The members of the project team management actively worked with specialist 2 , but the lack of soft skills had to be compensated by other team members, not by the expert in economics.

Project implementer: Executive member of the team with a sense of meeting deadlines, detail, stickler, team builder and coordinator, with the ability to complete the tasks assigned and project activities, diplomat of social intercourse and protocol, harmonized time periods set, convened meetings, coordinated written project documents, reported obtained and achieved internal results / outputs of member teams with outsources outputs into a complex project manual. The project implementer accepted the visions and integrated them into the business plan. It was a person with a high share of conceptual and technical competencies, behavioural competencies with a predominance of creativity, work performance, reliability, negotiation skills, and the ability to deal with conflicts and crisis and stress situations.

As a team, the selected team members created, implemented and finally handed over one of the most successful business projects in the Czech Republic. In terms of evaluation and erudition of the author of the contribution in the implementation of the start-up phase of the above-mentioned business project, it can be stated that the human factor impact on the business project success/failure is an equivalent of success/failure, where the human factor is not considered in terms of an individual, but of the project team with optimally integrated personalities.

\subsection{Negative influence of personality on business project success}

Table 6. Basic project definition II

\begin{tabular}{|l|l|}
\hline Sector & Civil engineering. \\
\hline Name of project & Improvement a restructuring of company \\
\hline Final consumer & Project submitter \\
\hline Position of project manager & Team leader and Interim manager \\
\hline Location & East Bohemia \\
\hline Project submitter & Regional producer of steel constructions \\
\hline Number of project team members & 6 (Project leader, specialist, implementer, coordinator) \\
\hline Method of implementation & Achievement of required economic indicators over time \\
\hline Sources & CZK $3,500,000$ \\
\hline Time & 12 months \\
\hline
\end{tabular}

Source: Own processing. 
The company breaking into market in 1992 was directed by the management of owners, i.e. members of a private limited company. Its added value has year-to-year lowered since 2008 while the negative aberration of the added value was higher than the decrease of its total revenues. The company owners decided to restructure the company in a project in 2011 . The project management was entrusted to an external manager - a restructuring expert who won the tender. The project team was picked in accordance with owners from internal resources of the company management. The primary task confronted the sequences in individual segments of the business economy and processes, e.g. cash-flow, expenses, process transparency, personnel, business revival and update of system procedures.

The project manager: is an external specialist with great professional and technical competences in the area of mechanical engineering, business economy and the economics of legal awareness who applied a directive style of the management of the project team with one-way communication. Its members called him an authoritarian since he had not shown any signs of behavioural competence in negotiations, discussions, mutual understanding and communication, openness and self-control. What was appreciated were personal traits such as ambition, endurance, independence, goal-mindedness, the trait of which initiated the restructuring process and crisis project management (the author marked him as 'Archer').

The project specialist: is an internal worker/expert - the current chief financial officer. $\mathrm{He}$ is an important person with a university education in the relevant field of study. He is on the long term basis associated with the company disposing of technical and professional competences in the area of financial management and planning, controlling and tax records. $\mathrm{He}$ is the general manager appointed to the project team by owners of the company. Unfortunately, the role of the chief financial officer and the project specialist were not identical throughout the implementation of the business project. The chief financial officer considered the position held as a threat and degradation to his present job. In regard to erudition and author's own terminology, he is marked as 'Teddy'.

The project implementer: is an internal worker/tuner, present HR manager familiar with the social environment of the company who has developed behavioural competences and disposes of amication elements and who also knows individual internal workers. The project implementer has professional and technical competences in Labour Law and he identifies himself with the business project. With respect to a long-term influence of the labour market and employment rate, he considered the project implementation as necessary and he did not impose any measures for reducing jobs.

The project coordinator: is a member of the project team of the internal environment of the secretariat of the company owner; the project coordinator was also a coordinator, administrator, tuner and cementer (a person that glues the team together). The personality of the project coordinator can be described as well-balanced with the equal proportion of participation in various areas of competence. Her pros were prioritizing the team cooperation, quality and carefulness in drafting written documents, knowledge of business processes, basic legal awareness, and knowledge of IT, issuing internal regulations and workflows. Her behavioural competences included the art of communication, presentation and negotiation.

The project implementer 1 and 2: are internal technical workers who worked on the business project, as had been required by the project call and assignment, simultaneously, having their own job outside the project by contract based on an agreement to complete a job. In regard to competences and skills, they mostly focused on the implementation of business systems and products in the area of health and safety at work. They display behavioural competences such as reliability, understanding of true values, effectiveness and usefulness of the business project. These implementers did not examine larger context of the project; however, the supported and stimulated operational activities of the business project.

The personnel of project team II and its own implementation failed to achieve required parameters and thus to implement the project itself. During the project's life cycle, the 
cooperation with the project manager/team leader was discontinued and an outsourcing external restructuring company was admitted to complete the project.

The causality of the business project might be defined as follows:

1. A complete lack of behavioural communication and presentation competences and social skills of the project manager/team leader; a considerable fluctuation of continuous and direct communication with members of the project team; the explanation of necessary restructuring measures-to-be caused a negative attitude of the team which negatively influenced the business project which resulted in reducing the personnel in the company.

2. The choice of project team members from managers of internal resources who had been internal workers even in pre-project phases was not optimal. In order to make necessary mends, i.e. systematic changes according to global trends and future expectations, it was necessary to cooperate with managers/team leaders who are interested and ambitious to promptly change the existing state and swiftly respond to it; at the same time, they should not be associated with the existing organizational structure of the company.

3. Company owners' interventions in the project management in the phase of team formation, which preferred members from internal personal resources in order to reduce overheads and labour costs and which admitted an external restructuring company, completed the project without a project manager/team leader.

4. The lack of behavioural competences of the project manager/team leader resulted in so called 'stagnation' of activities within the project team: i.e. individual team members focused only on themselves and not on the team and its close cooperation. In addition, open communication broke down which resulted in a breakdown in communication and barriers.

With the view to the depicted project management in relation to examining the influence of the human factor on the success/failure of a business project we might argue that neither great managerial competence counterbalances the lack of behavioural competences in communication skills, negotiation, leadership, assertion, conflict settlement and resolving crisis and stress situations. If the project team had been well-balanced with the focus on integrity and team members had developed behavioural competences and motivation stimuli, the likelihood of the successful completion of the business project would have been strong, although the project manager/team leader and the contracting authority is responsible for the failure of the project.

\section{Conclusions}

The analytical part compared two different project teams in different branches of entrepreneurship. Although the requirement for the project management is set out in instructions, resources and time according to the project triple constraint, each project is original and unique in its implementation and satisfying its expectations. The project resources include the most precious business resource - human capital. Unfortunately, this unique capital quantity is the hardest for the sociological measuring and persistence; therefore, it exerts the biggest influence not only on the success of the business project in regard to the successful completion of the project, but also a negative impact on the failure of the project.

The summary evaluation of findings provides a direct answer to causal stimuli of the influence of the human factor on the success/failure of the business project in these segments:

1. The influence of external interested subjects including individuals from enterprises, banks, interested groups of investors, competing companies and other strategic subjects and institutions; the whole number of these individuals 
have their particular interests which may influence the success/failure of the business project in both ways. A systematically managed project must not only know how to exercise positive influences and convert them into success, but also predict negative influences and reduce them to minimum.

2. Internal subjects of the interested organization as a contracting authority and important persons of the business project are of a strategic significance, as the company not only funds the project, but also changes the approach and comfort of involved persons who may participate in influencing the project in the both ways. The project team and contracting authority are responsible for the risk management of the project.

3. The influence of the project manager/team leader as a human factor on the success of the project is the key determinant to the expected success of the business project.

The summary evaluation in the theoretical and practical part of the article defines and recommends necessary competences and personal traits as follows:

- Qualification standards in technical, behavioural and conceptual competences.

- Personal charm, due respect and natural traits of the person.

- Ambitions, discipline and determination to achieve sth.

- To be a leader to yourself and also to the project team.

- Promptly respond to partial changes.

- Use the 'common sense'.

These coherent parameters of human factor significantly influence the success/failure of the business project.

\section{References}

1. A. Gorod, L. Hallo, T. Nguyen, A Systemic Approach to Complex Project Management: Integration of Command-and-Control and Network Governance. Systems Research and Behavioral Science, 35(6), 811-837 (2018)

2. H.T. Nguyen, B. Hadikusumo, Impacts of human resource development on engineering, procurement, and construction project success. Built Environment Project and Asset Management, 7(1), 73-85 (2017)

3. J. Doležal, P. Máchal, B. Lacko, Projektový management podle IPMA [Project management according to IPMA]. Prague: Grada (2012)

4. E. Mtsweni, Effect of technical issues and soft issues towards team performance and project success. 2017 IEEE AFRICON: Science, Technology and Innovation for Africa, AFRICON 2017, pp. 957-962 (2017)

5. A.R. Gilal, J. Jaafar, M. Omar, S. Basri, A. Waqas, A rule-based model for software development team composition: Team leader role with personality types and gender classification. Information and Software Technology, 74, 105-113 (2016)

6. M. Taghavi, H. Taghavi, M. Taghavi, Research project leadership stipulation system. Campus-Wide Information Systems, 30(4), 266-287 (2013)

7. E. Ambrozová, J. Koleňák, D. Ullrich, V. Pokorný, Corporate environment and the abilities required of professional managers. Proceedings of the 25th International Business Information Management Association Conference - Innovation Vision 2020: From Regional Development Sustainability to Global Economic Growth, IBIMA 2015, pp. 753-769 (2015) 
8. K.L. Cullen, W.A. Gentry, F.J. Yammarino, Biased self-perception tendencies: Selfenhancement/self-diminishment and leader derailment in individualistic and collectivistic cultures. Applied Psychology, 64(1), 161-207 (2014)

9. R. Bautista-Mesa, H. Molina Sánchez, J.N. Ramírez Sobrino, Audit workplace simulations as a methodology to increase undergraduates' awareness of competences. Accounting Education, 27(3), 234-258 (2018)

10. R. Štefánek, K.H. Bočková, How to manage risks in Czech and Slovac engineering projects. E a M: Ekonomie a Management, 14(4), 67-77 (2011)

11. M. Taylor, Začínáme ř́dit projekty [We are starting to manage projects]. Brno: Computer Press (2007)

12. H.S. Ng, D.M.H. Kee, T. Ramayah, The role of transformational leadership, entrepreneurial competence and technical competence on enterprise success of ownermanaged SMEs. Journal of General Management, 42(1), 23-43 (2016)

13. M.Y.A. Alsabbah, H.I. Ibrahim, Employees' competence and job performance. Advanced Science Letters, 23(1), 313-316 (2017)

14. N. Gruden, A. Stare, The Influence of Behavioral Competencies on Project Performance. Project Management Journal, 49(3), 98-109 (2018)

15. J.R.S.C. Mateo, E.D.R. De Navamuel, M.A.G. Villa, Are project managers ready for the 21thchallenges? A review of problem structuring methods for decision support. International Journal of Information Systems and Project Management, 5(2), 43-56 (2017)

16. Q. Wen, M. Qiang, Project Managers' Competences in Managing Project Closing. Project Management Journal, 50(3), 361-375 (2019) 